Uralic studies, languages, and researchers

Edited by Sándor Szeverényi 
Studia uralo-altaica 54

Redigunt:

Katalin Sipőcz

András Róna-Tas

István Zimonyi 
Uralic studies, languages, and researchers

Proceedings of the $5^{\text {th }}$ Mikola Conference 19-20, September 2019

Edited by Sándor Szeverényi

Szeged, 2021 
(C) University of Szeged,

Department of Altaic Studies,

Department of Finno-Ugrian Philology

All rights reserved. No part of this book may be reproduced, stored in a retrieval system, or transmitted in any form or by other means, electronic, mechanical, photocopying, recording or otherwise, without the prior permission in writing of the author or the publisher.

Printed in 2021.

Printed by: Innovariant Ltd., H-6750 Algyő, Ipartelep 4.

ISBN 978-963-306-803-8 (printed)

ISBN 978-963-306-804-5 (pdf)

ISSN 0133-4239 (Print)

ISSN 2677-1268 (Online) 
Table of contents

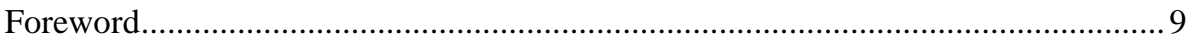

Sándor Szeverényi

Notes on Nicolaes Witsen and his Noord en Oost Tartarye. 11 Rogier Blokland

Undiscovered treasures: From the field research archive to the digital database......27 Beáta Wagner-Nagy, Chris Lasse Däbritz, and Timm Lehmberg

On the language use of the first Finnish medical text 45

Meri Juhos

Sajnovics, the responsible fieldworker 55

Sándor Szeverényi

The life and work of the Saami theologian and linguist: Anders Porsanger 71

Ivett Kelemen

The use and semantics of the Northern Mansi diminutive -riś $r \partial s$ ś 81

Bernadett Bíró

The event of "giving" and "getting" in Siberian Uralic languages 99

Katalin Sipöcz

A word-formational approach to neologisms in modern Northern Mansi

Susanna Virtanen

Word and stem repetitions in the heroic epic songs collected by Antal Reguly ..... 131 Mária Sipos

The use of body part terms in expressing emotions in Udmurt 149

Rebeka Kubitsch

The characteristics of responses given to compliments in Udmurt 173

Zoltán Németh

On some Chuvash-Mari shared lexemes and Agyagási's "Late Gorodets" hypothesis .. 185 Christopher Culver 
“Сувениры Севера" Minority identity and discourse. Representation of indigenous minorities of Northern Russia in the digital media. The case of Dudinka ........... 201 Zsuzsa Várnai and Ágnes Hámori

Reconsidering the Nganasan vowel system 229 László Fejes

New aspects in the study of Mari, Udmurt, and Komi-Permyak: The Typological Database of the Volga Area Finno-Ugric Languages 255 Erika Asztalos, Nikolett F. Gulyás, Laura Horváth, and Bogáta Timár Ethnosyntax in Siberian Uralic Languages (a project report) 275 Bernadett Bíró, Katalin Sipöcz, and Sándor Szeverényi 


\title{
Word and stem repetitions in the heroic epic songs collected by Antal Reguly
}

\author{
Mária Sipos \\ Hungarian Research Centre for Linguistics, Budapest \\ "Repetition, therefore, serves to conjure up a world \\ in which nothing is hurried: \\ actions are elaborated at a deliberate pace; \\ even in the heat of battle \\ the words are exchanged with a degree of formality. \\ This audience enjoys the poet's play on the patterns \\ they have come to know; \\ it is essential to their experience of oral song. \\ They find pleasure in traditional forms and traditional strategies; \\ and it gives them pleasure \\ to observe the poet working inventively with this same material."
}

(Minchin 2016: 27, 28)

\section{Introduction}

In November and December 1844, Antal Reguly collected 12 heroic epic songs from an old Khanty singer, Nikilov Maxim, and this collection constitutes the only documentation of the Sygva dialect. Of this folklore material, the heroic epic songs amounting to about 17,000 lines were processed, translated, and published by Hungarian scholars (ONGy, OH I, OH II, OH III/I, OHIII/II). Since publication, the epic songs have been investigated from various aspects, e.g. metrics (Austerlitz 1958, Schmidt 1990), linguistic issues (the grammaticalization of present and past participles, A. Jászó 1976), historical perspectives, typological subgroups of the genre (Demény 1977, 1978), cognitive mechanisms in parallel lines (couplets) (Bakró-Nagy 1985), and formulas (Widmer 2001), and were also used as a source for historical studies and cultural anthropology (Hatto 2017). But despite all this research, Nikilov DOI https://10.14232/sua.2021.54.131-147 
Maxim's heroic epic songs are still not widely known internationally in folklore research.

The heroic epic has been in the focus of attention for a long time because of what has been termed the Homeric question, which in fact consisted of several subquestions, namely, how the Iliad and Odyssey came into being, whether they are works of a single poet or a number of contributors, how singers memorized long texts etc. Investigations carried out by Milman Parry and Albert B. Lord revealed that long poems can be transmitted orally, and the composition of folklore texts of this type takes place during the performance itself. These findings generated interest in the specifics of oral poetry, or rather, in verbal improvisation. Most research in the field has concentrated on the mnemotechnic function of repeated structural units, i.e. subformulas, formulas, type scenes, and rhetorical figures. Later this one-sided approach was criticized, claiming that numerous important aspects had been neglected, e.g. poetic and aesthetic functions, the significance of cultural background etc. (Delić 2015).

These days, there are investigations concentrating on, among other things, the cooperation of singer and audience. Minchin (2016) analyzes types of repetition in the Homeric epic, laying great emphasis on the interests of listeners processing long poems. She highlights that "oral song imposes far greater demands on both the poet and his audience than everyday talk imposes on a group of speakers" (Minchin 2016: 14). Regarding the singer, fluency is a natural requirement, the performance is monologic, and lasts typically for a long time. As far as the listeners are concerned, limitations of memory and attention constrain them also as they process the poem (Minchin 2016: 15). Minchin also emphasizes that the specific language of epic poetry using formulas and many other manifestations of repetition slow the presentation of new information and allow listeners to absorb it. "....[I]ndeed, capacity in short term memory is freed up so that the listener can focus on the storyline and absorb the poet's evaluative cues" (Minchin 2016: 16). These claims explain the importance of repetition techniques also in Ob-Ugric poetry.

Repetition is the most salient feature of the language of Ob-Ugric folklore, manifesting itself in various forms. Its significance was recognized already at the beginning of processing Khanty and Mansi folklore texts. Austerlitz began the summary of his findings in his fundamental monograph on Ob-Ugric metrics with the sentence "[t]he over-all feature of Ob-Ugric metrics is varied repetition" (Austerlitz 1958: 123). Although he concluded claiming that parallelism is the most common and characteristic type of repetition, in his work he gives a careful analysis also of etymological figures (Austerlitz 1958: 108-119).

Decades later, Schulze claimed that the technique of building etymological figures must have been vivid, and places an emphasis on the dichotomy of two mechanisms 
during the process that is called composition-in-performance by folklorists, namely, invoking invariable figurae etymologicae, as well as the singers' freedom in creating and using them (Schulze 1975: 684).

The objective of the present paper is to describe some characteristic features of the figura etymologica used in northern Khanty folklore on the basis of the heroic epic songs collected by Antal Reguly. The investigation does not include a comprehensive description of all types of the figura etymologica as such classifications have already been written.

In this paper, the figura etymologica, along with other similar rhetoric schemes, is not considered to be a stylistic device aiming to produce a poetic effect. From a metrical point of view, the role of this type of repetition in the building up of lines has been discussed in the above mentioned monograph by Austerlitz (1958). In what follows, items of intra-sentential repetition are regarded as devices that can support singers in creating texts totaling hundreds of sentences, i.e. during composition-inperformance, on the one hand, and as features of the given folklore material that can ease the task of listening and comprehending on the other hand.

The main questions are the following: to what extent are figurae etymologicae fixed and static elements of the text which are called up as invariable units? and are there signs of flexible usage, which gives significant scope for the singer's creativity?

\subsection{Terminology}

Among the numerous rhetoric schemes, it is the figura etymologica that is most often mentioned when discussing Ob-Ugric intra-sentential repetition. It is typically defined as words of the same etymological derivation that are used relatively close (Todd 2009b: i) or in close proximity to each other (DCC) (1):

(1) So long lives this, and this gives life to thee' (Sonnet XVIII, Shakespeare)

In addition, for identifying the rhetoric devices of the Sygva Khanty heroic epic, polyptoton is also needed. Polyptoton is the repetition of the same word with various inflection (DCC) (2):

(2) Then know that I, one Snug the joiner, am/ A lion-fell, nor else no lion's dam. (Midsummer night's dream, Shakespeare)

In short, the main difference between the two is morphological: the constituents of a figura etymologica are derived from the same root, while those of a polyptoton are inflected forms of the same word.

There is a further type of repetition in the folklore texts in question that hardly needs any terminological clarification. It is word repetition, i.e. when a word occurs within the clause twice or more in the very same form but in different phrases. 


\subsection{Ordering of discussion}

In Section 2, a quantitative survey will be discussed, concentrating on the frequency of various kinds of repetitions realized within the boundaries of a line. In Section 3, those types of etymological figures will be introduced that have proven to be characteristic of the Synja Khanty material. In addition, it is emphasized that verbal phrases allow more flexibility for creating etymological figures than noun phrases. Then, in Section 4, it will be shown that, regarding the actual realizations of formulas, the figurae etymologicae are often optional. Furthermore, it will be illustrated that they are not necessarily fossilized phrases but are adjusted to the actual semantic requirements of the sentence.

Quantitative data are given on the basis of the survey of Jeli us eri (OH 1: 166486), however, examples will be given from various epic songs.

Khanty data will be quoted in the original form recorded by Reguly. Stem and word repetitions will be indicated with bold letters, other details are highlighted with underlining. As parallelism and the realizations of intra-sentential repetition do not inevitably coincide, parallel lines are not taken into consideration, i.e. either the first or the relevant line will be quoted, depending on the actual position of the repetition in question.

\section{The proportion of lines containing figurae etymologicae}

On the basis of a heroic song from the archaic subtype, and another one from the new pieces, the proportion of lines exhibiting the figura etymologica is between 10-15\%.

POLM, ${ }^{1}$ belonging to the archaic heroic songs, consists of 617 lines. Nineteen lines express characters' names, which are regularly multi-word phrases occupying a whole line, so the figura etymologica is not likely to occur in them. As there are 60 lines containing the figura etymologica, it results in about $10 \%$.

Regarding JELI, ${ }^{2}$ a heroic song of the later types, the total number of lines is 2,795. Names of characters are given in 202 lines, and 521 lines bear the figura etymologica, which amounts to $18.6 \%$ of the lines.

\footnotetext{
${ }^{1}$ POLM = Polm torom ar. A pelimvidéki isten éneke [Song of the god of the Pelim region]. ONGy 69-99.

${ }^{2}$ JELI = Jeli us eri. Jeli város éneke [Song of the village of Jeli]. OH I. 166-487.
} 


\begin{tabular}{|l|c|c|}
\hline \multicolumn{1}{|c|}{ Song } & POLM & JELI \\
\hline Number of lines & 617 & 2,795 \\
\hline Number of lines describing heroes' names & 19 & 202 \\
\hline Number of lines apart from enumeration & 598 & 2,593 \\
\hline Lines containing figurae etymologicae & 60 & 521 \\
\hline Percent & $10 \%$ & $20 \%$ \\
\hline
\end{tabular}

Table 1. Data of lines containing the figura etymologica

According to Todd (2009a), same-clause repetition of the same stem occurs roughly once every 100 lines in the Iliad, and once every 50 lines in the Odyssey. Converting the above percentage, in Reguly's heroic songs, the figura etymologica appears once every 10 (archaic heroic song), or once every 5 to 6 (new type) lines, which is several times its respective proportion in the Homeric epic. As sentences are divided into several lines, this proportion would be even more impressive if we referred to sentences.

In conclusion, regarding quantitative aspects, all the above numbers prove that the figura etymologica plays an important role in the Khanty oral epic tradition.

\section{Types of the figura etymologica in the northern Khanty heroic epic}

Steinitz described the most important types of figura etymologica found in northern Khanty dialects (Steinitz 1976, first published in 1941), namely, two nominal groups and a verbal one, to which some further subtypes were added later by Schulze (1975), as a result of her survey of the Sygva Khanty folklore texts collected by Reguly. Steinitz and Schulze both differentiated nominal and verbal types, as well as some minor subgroups. Their classifications give similar overviews, i.e. figurae etymologicae belonging to a noun phrase show a greater extent of regularity and fewer subgroups compared to those belonging to the verbal part of the sentence.

Widmer, in her monograph on the formulas found in a heroic epic material very similar to Reguly's heroic songs, provides a thorough analysis of the structure of formulas containing a figura etymologica as well (Widmer 2001: 134, 144). Widmer processed the material mainly in relation to the metrical structure of the lines, and in her work only the figurae etymologicae belonging to the nominal group are described. This type of formulas can be described with the term subformula as they can combine with various verbal parts resulting in formulas differing in content (Sipos 2019).

Austerlitz (1958) also specified several types of figurae etymologicae, revealing their syntactic background when needed. In his analysis, the proximity of repeated elements played an important role, and he focused mainly on figurae etymologicae 
within noun phrases, sometimes discussing ones covering also the verbal part of the sentence.

He differentiated figurae etymologicae from pure repetitions (Austerlitz 1958: 109-119).

In sum, the analyses typically concentrate on the figurae etymologicae operating within a noun phrase, and, thus, much less importance was attached to nominal-verbal and participial-verbal ones. However, in the heroic epic song processed in the present paper, the proportion of the purely nominal figurae etymologicae and the remaining types suggest that these two main groups are of similar importance.

\subsection{The figura etymologica in noun phrases}

The nominal etymological figures essentially cluster around two basic patterns. This is in accordance with the results of Steinitz and Austerlitz, who processed large corpora and enumerated several types of the figurae etymologicae, which are not of the same abundancy in their corpora (Steinitz 1976, Austerlitz 1958). Regarding the Sygva Khanty epic material, not all of Austerlitz' groups are represented in it. In JELI, the epic song used as a corpus of qualitative analysis, there are 294 nominal figurae etymologicae including 258 ones belonging to Type [ $\left.f^{\prime} A f^{\prime \prime}\right]$, and 32 to Type [ $A f^{\prime} f^{\prime \prime}$ $B],{ }^{3}$ leaving 4 to further small groups (3) (4):

(3) URTE$^{4}-0440$

sänz-ing vuăs sass $^{5}$-l-ä jogot-l-em

back-DER $_{\text {ADJ }}$ town back-3SG-LAT arrive-PRS-1SG

'I arrive at the back of the town that has a back part'

(4) $\mathrm{ASSP}^{6}-0543$

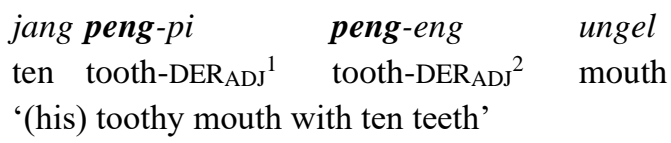

${ }^{3}\left[f^{\prime} A f^{\prime \prime}\right]$ and $\left[A f^{\prime} f^{\prime \prime} B\right]$ were introduced by Austerlitz to symbolize the structure of the figurae etymologicae; $f^{\prime}$ and $f^{\prime \prime}$ indicate the changing forms of the repeated item.

${ }^{4}$ URTE $=$ Urt enmem arl. A fejedelem felnevelkedésének éneke [Song of the prince's growing up]. OH II. 180-255.

${ }^{5}$ The nasal element of the stem final consonant cluster in the noun 'back' is deleted or not depending on the syllable structure of the inflected or derived word form.

${ }^{6} \mathrm{ASSP}=$ Ass pogol eri. . Ob-falu éneke [Song of the village Ob]. OH II. 3-119. 


\subsection{The figura etymologica in verb phrases}

In contrast, the verbal figurae etymologicae have more subgroups and show greater syntactic diversity.

\subsubsection{Participle-verb figures}

In this group, the first part of the figure is a participle (present or past), the second element, in turn, is the verbal predicate of the sentence. The etymological figures exhibiting this pattern occur in 133 lines of the corpus. Participle-verb figures are very diverse even within their own subgroup, i.e. the participles appear in various syntactic functions, and they can be attribute to the object or any adverbial of the sentence (5)-(7):

(5) JELI 0305

$\begin{array}{lllll}\text { untlti } & \text { kur-l } & \text { jirr } & \text { koti } & \text { untt-l-em } \\ \text { know.PTCP.PRS } & \text { foot-3SG } & \text { joint } & \text { how } & \text { know-PRS-1SG }\end{array}$

'This is how I recognize his foot joint to be recognized...'

(6) ASSP-0686

$\begin{array}{lllll}\text { in untä } & \text { măsing ord } & \text { kongolti } & \text { numang } & \text { joch } \\ \text { now until } & \text { perhaps hero } & \text { make.climb.PTCP.PRS } & \text { branch.DER } & \text { tree }\end{array}$

kongolt $\ddot{a}-s-\ddot{a}$

make.climb-PST-PASS.3SG

'So far, he may have been executed on the tree used to execute heroes.'

(7) JELI-1940

koleut kăr kill-ti aling suj aling tomorrow reindeer.bull get.up-PTCP.PRS morning noise earl

kil- $\ddot{a}$

get.up-IMP.SG2

'Tomorrow, wake up to the sound of reindeer getting up.'

There are numerous examples of the use of archaic participles ${ }^{7}$ known exclusively from folklore texts (8):

\footnotetext{
${ }^{7}$ In these participles the suffix $-\eta \partial n$ is attached to the participles ending in $-t,-m$, and $-l a$.
} 
(8) PAUT $^{8}-1087$

\begin{tabular}{|c|c|c|c|}
\hline jas-l & ke & tăgărle-l & \\
\hline hand-3sG & if & be.stuck-PRS.3SG & \\
\hline $\begin{array}{l}\text { lui+mang } \\
\text { sprayey(?) }\end{array}$ & $\begin{array}{l}\text { joch } \\
\text { tree }\end{array}$ & $\begin{array}{l}\text { veleg+tangen } \\
\text { snag-РТСР }\end{array}$ & $\begin{array}{l}\text { velech-l-em } \\
\text { snag-PRS-1SG }\end{array}$ \\
\hline
\end{tabular}

This subtype is represented in 22 figurae etymologicae, and they typically express similes whose syntactic function is adverbial of manner.

\subsubsection{Polyptoton}

In a further type, the finite verb of the sentence does not actually participate in the repetition, although the stem repetition itself exceeds a noun phrase. This type may be qualified as a polyptoton because the morphological difference between the two parts of the figure lies in only a case suffix. ${ }^{9}$ The scheme of this repetition type is the following: an adjective or a numeral appears first in its basic form, and then with a lative case suffix. This type is represented in 42 lines in the heroic song in question and is illustrated in (9) and (10):

(9) JELI-1355

$\begin{array}{llllll}\text { put-ing } & \text { lant } & j a ̈ m & \text { sop } & \text { put-ing-ä } & \text { le-l-eu } \\ \text { pot-DERADJ } & \text { food } & \text { good } & \text { bit } & \text { pot-DERADJ-LAT } & \text { eat-PRS-1PL }\end{array}$

'We are eating the delicious bit of cauldron food from the cauldron'

(10) JELI-0137

$\begin{array}{llclll}\text { lung-en } & \text { katl } & \text { kab-ung } & k i & \text { lăbed } & \text { moi } \\ \text { summer-2SG day } & \text { boat-DER } & \text { if } & \text { seven } & \text { wedding.guests } \\ \text { labt- } \ddot{a} & k \text { k } & \text { jăch-mel } & & \\ \text { seven-LAT } & \text { although } & \text { go-EVID.PST.3PL } & \end{array}$

'although on a summer day, seven separate groups of wedding guests with boats paid a visit'

In many cases, it seems to describe a change of state: however, the initial and final features, conditions etc. are the same, i.e. the semantics in this type can definitely have a tautologic character (11).

${ }^{8}$ PAUT = Puling-aut eri. Obdorszki ének [Song of Obdorsk]. OH I. 2-165

${ }^{9}$ This was also claimed by Schulze (1975: 682), although she does not use the technical term polyptoton. 
(11) JELI-1294:

$\begin{array}{llllll}\text { juh } & \text { uni } & \text { kolim } & \text { schelm-el } & \text { kolm- } a & \text { tag-os } \\ \text { wood } & \text { big } & \text { three } & \text { spall-3SG } & \text { three-LAT } & \text { rip-PST.3SG }\end{array}$

'Three big spalls of the wood ripped into three.'

Nevertheless, as is illustrated in (12), adverbials of mode are normally derived from adjectives with the derivative suffix $-a$, which is historically identical with the lative case suffix $-a$.

(12) JELI-2553

\begin{tabular}{|c|c|c|c|}
\hline put & vur- $i$ & ălng-el & \\
\hline black & blood-DER ${ }_{\text {ADJ }}$ & end-3SG & black-LAT \\
\hline \multicolumn{4}{|c|}{ temes-tal } \\
\hline & S.3SG & & \\
\hline ' $\mathrm{His} \mathrm{b}$. & od flows black & & \\
\hline
\end{tabular}

\subsubsection{Noun-verb figures}

There are examples of figura etymologica in which the stem of the sentence final finite verb is repeated as a noun, either as a stem or in derived form. There are 20 occurrences of this type (13)-(15):

(13) JELI-0295

$\begin{array}{llll}\text { unt } & k o j-i & \text { noms-em } & \text { nomes-l-em } \\ \text { forest } & \text { man-DERADJ } & \text { brain-1SG } & \text { think-PRS-1SG }\end{array}$

'I'm speculating with my forest man brain.'

(14) JELI-1598

$\begin{array}{llllll}\text { jas-l } & \text { pelek } & \text { jäm } & \text { amtep } & \text { schirtnet } & \text { amtellyi-ly } \\ \text { hand-3SG } & \text { half } & \text { good } & \text { exultation } & \text { then } & \text { rejoice-PRS.3SG }\end{array}$

'Then he is doing a one-hand jubilation.'

(15) JELI-0486

$\begin{array}{lllll}\text { lănge } \quad k o \quad \text { ălm-en } & \text { iet }^{10} & \text { schi } & \text { ăl-l-en } \\ \text { ancestral.idol man dream-2SG } & ? & \text { PTC } & \text { sleep-PRS-2SG } \\ \text { 'You sleep an idol's sleep.' } & & & \end{array}$

\subsection{Pure repetition}

The following type is classified as pure repetition by Austerlitz (1958: 116), which differs from the figura etymologica in that the repeated words are attributes to two

${ }^{10}$ Unknown meaning. 
different nouns. The number of lines containing this type of repetition is 50. It is illustrated with (16) and (17):

(16) JELI-1316

$\begin{array}{llll}\boldsymbol{k} \boldsymbol{u} \text { poter } & \boldsymbol{k} \boldsymbol{u} \text { kas ames-l-eu } \\ \text { long discourse long joy } & \text { sit-PRS-1PL } \\ \text { 'We solemnize the long joy of long discourse.' }\end{array}$

(17) JELI-1856

$\begin{array}{lllll}\text { labed } & m u & \text { zung }^{11} & \text { labed } & \text { ort-en } \\ \text { seven } & \text { land } & \text { region } & \text { seven } & \text { hero-2SG }\end{array}$

'your seven heroes from seven regions'

\subsection{Further types}

In addition to the above mentioned types, there are some cases in which the basic viewpoints are not enough to classify the clauses containing the figura etymologica, and there are patterns of lower incidence rate.

\subsubsection{Triple figurae etymologicae}

Triple figurae etymologicae are created by combining a verbal type with a nominal one (Schulze 1975: 684). The following pattern should be regarded as a Type [ $f^{\prime} A$ $\left.f^{\prime \prime}\right]$ applied together with a [Noun + verb] stem repetition (18):

(18) JELI-0049

mиi nem-ing ord nem-em nemi-l-ä what name-DERADJ hero name-1SG name-PRS-PASS.3SG

'By what name is my hero's name named / By what famous name am I mentioned?'

\subsubsection{Mixed types}

The above tautologic construction containing a lative case construction and classified as a polyptoton (see 3.2.2 above; cf. example 11) can be expressed with participial constructions (19):

${ }^{11}$ Reguly: muzung. 
(19) JELI-1646

$\begin{array}{llll}\text { säss } \text { belä } & \text { käi-ti } & \text { ar } & \text { kăt-em } \\ \text { back toward } & \text { leave-PTCP.PRS many house-1SG } \\ \text { sass } \text { belä } & \text { kai-temen } & & \\ \text { back toward } & \text { leave-EVID.PRS.1DU } & \\ \text { 'We leave the houses to leave behind us behind us.' }\end{array}$

The lative case construction can further be enriched with word repetition, resulting in a combination of a polyptoton and a pure word repetition, cf. 3.4.1 (20):

(20) JELI-1603

\begin{tabular}{|c|c|c|c|c|}
\hline $\begin{array}{l}\text { labed } \\
\text { seven }\end{array}$ & $\begin{array}{l}m u \\
\text { region }\end{array}$ & $\begin{array}{l}\text { zung } \\
\text { corner }\end{array}$ & $\begin{array}{l}\text { seu-l } \\
\text { braid-3sG }\end{array}$ & $\begin{array}{l}\text { senhl-em } \\
\text { grow-PTCP.PST }\end{array}$ \\
\hline$n a i$ & labt-a & & latlti-mem & \\
\hline woman & seven-1 & & make.fly-E & \\
\hline
\end{tabular}

'I made fly seven women with braids and coming from seven regions.'

\section{The figura etymologica: static or dynamic?}

There are some phenomena suggesting that, although the text of oral epic is generally based on formulaic language, the figura etymologica should not be considered automatically a part of a fossilized construction in every case. In what follows, I give some examples of two features of the use of stem repetition that illustrate the above observation.

\subsection{The figura etymologica and variability}

There are formulas that seem very similar to each other in the sense that the etymological figures in them are arranged around the same words as central elements, e.g. 'boat', 'town', or 'house.

Intrinsically, they are possessive constructions with the same possessor but with a different possessee, which latter, with the adjective of the possessee, actually constitute stem repetition. These formulas are intended to express direction or other detailed information about the place of the activity denoted by the verb, e.g. 'onto the roof of a house', 'in the corner of the house', 'from the aft end of a boat', 'in the spacious inner part of the village', 'to the dock of the town/village' etc. In other words, the representatives of this type of construction seem to be a result of combining various techniques, i.e. applying the [Adj - Possessor - Possessee] construction and generating figura etymologica at the same time, so they are not necessarily static, invariable, three-word formulas. The following examples exhibit constructions in which the central element is a boat (21a-f). 
(21a) JELI-0328

langl-en kăp lăngl-el eult ${ }^{12}$

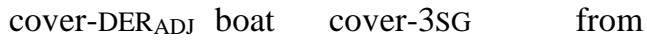

'from the cover of the boat having a cover'

(21b) JELI-0746

$\begin{array}{lll}\text { lipe }-n & k \breve{a p} & \text { lipe-l-nä } \\ \text { inner.part-DER } & \text { boat } & \text { inner.part-3SG-LOC }\end{array}$

iln long-tel

down enter-EVID.PRS.3PL

'they go down into the boat having an inner part'

(21c) JELI-0804

$\begin{array}{lll}\text { seuss-eng } & k a ̆ p & \text { seuss-el-nä } \\ \text { wheel-DER } & \text { boat } & \text { wheel-3SG-LOC }\end{array}$

'at the wheel of the boat having a wheel'

(21d) JELI-0672

pus-en kăp pus-el ${ }^{13}$

aft-DERADJ boat aft

'from behind the boat having a back part'

(21e) JELI-1432

$\begin{array}{llll}\text { jelpi } & \text { katl } & \text { sai-l-na } & \text { nyol-eng } \\ \text { previous } & \text { day } & \text { hidden.place-3SG-LOC } & \text { nose-DERADJ } \\ \text { kăp } & \text { nyăl-en } & \text { katl-em } & \text { ko } \\ \text { boat } & \text { nose-2SG } & \text { catch-PTCP.PST } & \text { man }\end{array}$

'the man who tied up the boat having a forepart by its forepart the previous day'

(21f) JELI-1490

\begin{tabular}{|c|c|c|c|c|}
\hline$n a ̈ n \xi$ & jelpe- $n$ & siing & $k a ̆ p$ & sing-em ${ }^{14}$ \\
\hline $2 \mathrm{SG}$ & before-2SG & crook.DER ${ }_{\mathrm{ADJ}}$ & boat & crook-1SG \\
\hline
\end{tabular}

'if I had tied up my boat having a crook earlier than you'

The very same observations can be made about the subformulas containing 'house' or 'town' as the possessor of the construction. In other words, such sets of nominal

12 Reguly: lăngle leult.

${ }^{13}$ In the Hungarian translation it is indicated that the ablative postposition (Reguly: eult) is expected to follow the noun (OH I: 242).

${ }^{14}$ Reguly: singemke. 
formulas prove that the singer not only invoked fixed phrases but also applied rules for building phrases with the etymological figure creatively, according to the semantic needs of the sentence.

\subsection{The figura etymologica and optionality}

There are both nominal and verbal formulas that can appear either in a form containing the figura etymologica, or in a form without this rhetoric scheme. In the following examples, in each pair, (a) and (b) formulas exhibit the same syntactic pattern but (a) sentences include a stem repetition while (b) sentences do not (22a-25b):

(22a) JELI-1040

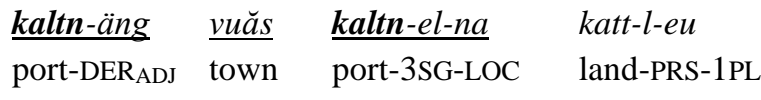

'We land at the port of the town that has a port.'

(22b) JELI-1179

$\begin{array}{llll}\text { täm } & \text { kaltn-äng } & \underline{v u a ̆ s} & \frac{\text { ilpe-l-na } a^{15}}{\text { thewn }} \\ \text { this port-DER } & \text { botom-3SG-LOC }\end{array}$

'at the bottom of the town having a port'

(23a) JEMA ${ }^{16}-0357$

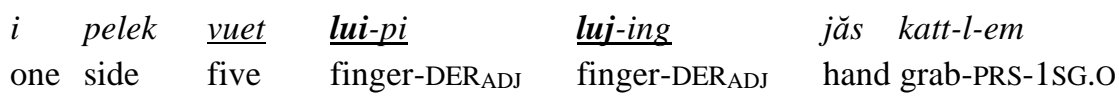

'I grab it with one of my fingery hands having five fingers'

(23b) UORT ${ }^{17}-1089$

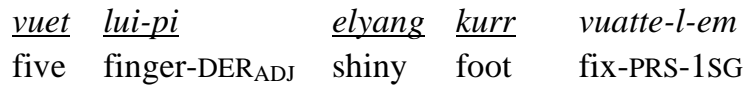

'I fix it on my five-finger shiny foot.'

(24a) MUNK ${ }^{18}-1073$

$\begin{array}{lllll}\text { sas } & \text { vuazi } & \text { ămes-tangen } & \text { iln } & \text { ămes-tal }^{19} \\ \text { ermine } & \text { duck } & \text { sit-PTCP } & \text { down } & \text { sit-EVID.PRS.3SG }\end{array}$

'[The old man śokor from the underworld] has dropped down similarly to a duck'

${ }^{15}$ Reguly: il pelna.

${ }^{16}$ JEMA = Jeming Ass mui ar. A szentséges Ob görbületének éneke [Song of the gut of the holy Ob river]. OH II. 120-180.

${ }^{17}$ UORT = Uort ar. Sarnyu uort arl. Fejedelemének. Az Aranyfejedelemnek ő éneke [Song of prince. Song of the Golden Prince]. OH III/I. 14-170.

${ }^{18}$ MUNK = Munkess Kănt Tărom eri. A munkeszi hadisten éneke [Song of the war god of Munkes]. ONGy 1-68.

${ }^{19}$ Reguly: il nămestal. 
(24b) JELI-2205

\begin{tabular}{lccl} 
jii-l & vuăs-em & kul-ing & pull \\
father-3SG & fish-PTCP.PST & fish-DERADJ & fish.trap \\
vuăs-tangen $^{20}$ & \multicolumn{2}{c|}{${ }_{\text {amselt-em }}$} & \\
fish-PTCP $^{\text {seat-PTCP.PST }}$ &
\end{tabular}

'(he) has dropped down as if he took a seat on his father's fish trap'

(25a) UORT-0753

$\begin{array}{llllll}\text { mărti } & \text { mi } & \text { ko } & \text { ar } & \text { neng-en } & \text { ass } \\ \text { southern } & \text { region } & \text { man } & \text { many } & \text { woman-2sG Ob } \\ \text { kaleu rohung } & \underline{\text { nyăch }} & & \underline{k \text { konnzäa }} & \underline{\text { nyăch-tel }} \\ \text { seagull } & \text { shrieking } & \text { laugh } & & \text { on.one's.back } & \underline{\text { laugh-EVID.PRS.3PL }}\end{array}$

'The numerous women of the man from the southern region are shrieking like $\mathrm{Ob}$ gulls.'

(25b) MUNK-0129

$\begin{array}{lllll}\text { männz-em } & \text { käenzsi } & \text { lăuat } & \text { ord ake-m-pa } \\ \text { pluck-PTCP.PST } & \text { teal }^{21} & \text { size.of } & \text { hero uncle-1SG-in.turn } \\ \text { lăr kaleu rohung } & \underline{n y a ̆ c h} & & \underline{\text { konnzä }} & \underline{\text { vuel-tal }} \\ \text { lake seagull shrieking } & \text { laugh } & \text { on.one's.back } & \text { make-EVID.PRS.3SG }\end{array}$

'My uncle, who is of the size of a plucked teal, is making the lake gulls' shrieking laugh.'

\section{Conclusion}

Repetition has a special importance during composition-in-performance. In addition, it plays an important role in the processing of texts from the point of view of the audience, which means that the use of the figura etymologica, as a typical kind of repetition in oral poetry, is motivated from both sides.

In the history of investigations of oral formulaic poetry, it was formulas that generally stood in the center of attention, as they are the components that can easily be mobilized either in a frozen form or creatively adjusted to the needs of the text.

However, in the investigation of Ob-Ugric folklore texts, great emphasis has been placed on rhetorical schemes because it had been recognized that manifestations of repetitions on various levels play a very important role in this oral tradition.

Besides parallelism, the most important way of repetition in the heroic songs in question is the figura etymologica. Polyptoton and pure word repetition, which have different morphological and syntactic characteristics, produce stylistic effects similar

\footnotetext{
${ }^{20}$ Reguly: vuăs tangen.

${ }^{21}$ Eurasian teal, cf. Steinitz (1966-1988: 0525): Krickente, Anas crecca.
} 
to the figura etymologica. In addition, they have the same motivations (metrics, technique of performance, role in cognitive processes), and they are possible to combine, consequently, these three rhetoric schemes were discussed together.

These three rhetoric schemes together exhibit a high incidence rate. In an archaic heroic song and another one from the new layers, they occur in 10-20\% of the lines. Compared to the data concerning the Homeric epic, these numbers represent a manifold greater occurrence of the above mentioned patterns, proving their significance in the Ob-Ugric folklore.

It has already been noticed that although the use of the figura etymologica is regulated by various rules, at the same time, singers can apply these rhetoric patterns creatively. The paper has focused on the details of the dual nature of handling and creating etymological figures in the course of the performance.

The results of the investigation show that the figurae etymologicae in verbal phrases, evidently for syntactic reasons, show greater variability. In other words, the main difference between nominal and verbal etymological figures lies in the number of main types and subgroups. Although nominal etymological figures seem to be more fixed, flexibility or variability occur in them. In the [Adj + Possessor + Possessed] construction, the phrases containing e.g. 'town', 'boat, 'house' as a central element proved to be diverse: they can be easily modulated according to the requirements of the sentence, i.e. they can express any place, direction or actuality that is necessary for describing the event, by means of modifying their lexical constituents.

Besides variability, another important feature of the use of the figura etymologica is optionality. Numerous examples prove that the etymological figures can be detached from other structural or stylistic units. Formulas expressing essentially the same content can occur in a form with or without a figura etymologica.

In fact, the individual formulas or any kind of a syntactic structure are not necessarily accompanied by the figura etymologica, in other words, the figura etymologica is an optional device that operates according to its own rules.

As the above investigations were carried out on the basis of one epic song, these results can be completed and specified by means of processing all the Sygva Khanty heroic songs collected by Antal Reguly.
Abbreviations
first person
2 second person
3 third person
ADJ adjective
ADV adverb
DER derivative suffix 


$\begin{array}{ll}\text { DU } & \text { dual } \\ \text { EVID } & \text { evidential } \\ \text { LAT } & \text { lative } \\ \text { LOC } & \text { locative } \\ \text { PL } & \text { plural } \\ \text { PTC } & \text { particle } \\ \text { PTCL } & \text { participle } \\ \text { PRS } & \text { present } \\ \text { PST } & \text { past } \\ \text { SG } & \text { singular }\end{array}$

\section{References}

A. Jászó, Anna 1976. Megjegyzések a particípiumból alakult verbum finitumok mondattanához az északi osztjákban [Notes on the syntax of finite verbs formed from participles in northern Khanty]. Nyelvtudományi Közlemények, 78: 353-358.

Austerlitz, Robert 1958. Ob-Ugric metrics: The metrical structure of Ostyak and Vogul folk-poetry. FFC 174. Helsinki: Suomalainen Tiedeakatemia.

Bakró-Nagy, Marianne 1985. A paralelizmus szemantikájáról (kognitív mechanizmusok a paralelizmusokban) [On the semantics of parallelism: Cognitive methanisms in parallelisms]. Mühelymunkák III. Budapest: MTA Nyelvtudományi Intézet.

Delić, Lidija 2015: Poetic grounds of epic formulae. In: Detelić, Mirjana and Delić, Lidija (eds), Epic formula: A Balkan perspective. Belgrade: Institute for Balkan Studies of the Serbian Academy of Sciences and Arts, 13-42.

DCC = Gildenhard, Ingo, Hodgson, Louise et al. (eds) Cicero / De Imperio Cn. Pompei. Dickinson College Commentaries. http://dcc.dickinson.edu/cicerode-imperio/rhetorical-terms. Date of access: November 15, 2019.

Demény, István Pál 1977. Az északi osztják hősi énekek tipológiai elemzése [A typological analysis of northern Khanty heroic epic songs]. Nyelv-és irodalomtudományi Közlemények, 21: 33-43.

Demény, István Pál 1978. Az északi osztják hősi énekek történeti fejlődése [The historical development of northern Khanty heroic epic songs]. Nyelv-és irodalomtudományi Közlemények, 22: 147-158.

Hatto, Arthur 2017. The world of the Khanty epic hero-princes: An exploration of a Siberian oral tradition. Cambridge: Cambridge University Press.

Minchin, Elizabeth 2016. Repetition in Homeric epic: Cognitive and linguistic perspectives. In: Mihailo Antovic and Cristóbal Pagán Cánovas (eds): Oral poetics and cognitive science. Berlin - Boston: Walter de Gruyter, 12-29. 
OH I. = Osztják hősénekek. Reguly A. és Pápay J. hagyatéka. Közzéteszi: Zsirai Miklós [Khanty heroic epic songs. The estates of A. Reguly and J. Pápay. Published by Miklós Zsirai]. 1944. Budapest: Magyar Tudományos Akadémia.

OH II. = Osztják (chanti) hösénekek II. Reguly A. és Pápay J. hagyatéka. Közzéteszi: Zsirai Miklós [Khanty heroic epic songs, vol. 2. The estates of A. Reguly and J. Pápay. Published by Miklós Zsirai]. 1951 Budapest: Akadémiai Kiadó.

OH III/I. = Osztják (chanti) hősénekek III/I. Reguly A. és Pápay J. hagyatéka. Zsirai Miklós hagyatékából közzéteszi Fokos Dávid [Khanty heroic epic songs, vol. 3/1. The estates of A. Reguly and J. Pápay. From the estate of Miklós Zsirai, published by Dávid Fokos]. 1963. Budapest: Akadémiai Kiadó.

OH III/II. = Osztják (chanti) hösénekek III/II. Reguly A. és Pápay J. hagyatéka. Zsirai Miklós hagyatékának felhasználával közzéteszi Fokos Dávid [Khanty heroic epic songs, vol. 3/2. The estates of A. Reguly and J. Pápay. From the estate of Miklós Zsirai, published by Dávid Fokos]. 1965. Akadémiai Kiadó, Budapest. ONGy = Osztják népköltési gyüjtemény. Reguly Antal hagyatéka és saját gyüjtései alapján közzéteszi Pápay József [A collection of Khanty folk poetry. From the estate of Antal Reguly and his own collection, published by József Pápay]. 1905. Budapest - Leipzig: Hornyánszky Viktor - Hiersemann, Karl.

Schmidt, Éva 1990: Az osztják metrika másik oldaláról [The other side of Khanty metric]. Nyelvtudományi Közlemények, 91: 181-194.

Schulze, Brigitte 1975. Zur ostjakischen etymologischen Figur. CIFU III. Pars 1. 681684.

Sipos, Mária 2019. Formula és típusjelenet a Reguly-hösénekekben [Formulas and typican scenes in the Reguly heroic epic songs]. Manuscript submitted for publication.

Steinitz, Wolfgang 1966-1988. Dialektologisches und etymologisches Wörterbuch der ostjakischen Sprache. Berlin: Akademie Verlag.

Steinitz, Wolfgang 1976. Zur ostjakischen und wogulischen Volksdichtung. In: Sauer, Gert and Schulze, Brigitte (eds), Wolfgang Steinitz: Ostjakologische Arbeiten. Band II. Budapest: Akadémiai Kiadó, 1-62.

Todd, C. Clary 2009a. Solemnity, banality and sarcasm: Provenances of the figura etymologica in Homer.

https://camws.org/meeting/2009/program/abstracts/11E3.Clary.pdf. Date of access: November 20, 2019.

Todd, C. Clary 2009b, Rhetoric and repetition: The figura etymologica in Homeric epic. https://pdfs.semanticscholar.org/f272/95c6bfcda71d29886c825fb7436434e10 1d9.pdf. Date of access: November 18, 2019.

Widmer, Anna 2001. Die poetischen Formeln der nordostjakischen Heldendichtung. Veröffentlichungen der Societas Uralo-Altaica 53. Wiesbaden: Harrasowitz. 